\title{
Chemical composition and nutritional evaluation of some natural and commercial food products based on Spirulina
}

\author{
L. Campanella*, G. Crescentini ${ }^{\dagger}$ and P. Avino \\ Department of Chemistry, University of Rome "La Sapienza", Piazzale Aldo Moro 5, 00185, Rome, Italy
}

\begin{abstract}
A natural and a commercial Spirulina product of Cuban origin have been extensively studied together with four algal food products available on the Italian market. The contents of macrominerals, trace elements, free and total amino acids, fatty acids and of two important phycobiliproteins (C-phycocyanine and allophycocyanine) have been determined. The results are compared with those of other studies regarding both natural and commercial analogous products. A nutritional and toxicological evaluation of the products was conducted. The analyses were performed using different analytical procedures: macrominerals and trace elements were determined by INAA and by ICP-AES, free and total amino acids (as PTC-derivatives) and phycobiliproteins were determined by HPLC analysis (with UV detection). Fatty acids were extracted using two different methods (one based on benzene and the other based on supercritical fluid extraction with $\mathrm{CO}_{2}$ ) and analyzed as esters by GC-analysis.
\end{abstract}

Key words. Spirulina platensis - algae - chemical composition - nutrition.

\section{Introduction}

Blue-green algae have been attracting the most attention as potential, indeed actual, sources of proteins and other human and natural nutrients (fatty acids, macro- and trace minerals). Among these algae, the filamentous cyanobacterium Spirulina appears to be a ubiquitous component of the phytoplankton growing in ocean and seawaters (from tropical lagoons to Arctic waters, thermal springs, alcaline lakes etc.) [1-3]. This alga is protein rich (up to $70 \%$ protein by dry weight), contains essential amino acids [4], is easily digestible and is much larger than unicellular alga which simplifies harvesting [5]. The low content of cholesterol and lipids [6,7] and the presence of minerals, vitamins, carbohydrates, essential fatty acids, sterols [1] and blue pigments, the phycocianins, which contribute to increase the protein and iron availability [8] have been also proven.

Further, the presence of an anti-oxidizing agent as $\beta$ carotene and the rare $\gamma$-linolenic acids [9,10] suggests [11] a beneficial therapeutic effect (first of all anti-cancer) of this alga.

It should be pointed out that Spirulina can be used as a fertilizing agent $[12,13]$ and for other not less important purposes such as treatment of urban wastewaters [14], while phycocyanins extracted from Spirulina are used as industrial and food coloring agents [1]. Their fluorescent properties have been exploited in bioanalytical techniques such as immunoassay analysis [15] and flow cytometry [16].

However, Spirulina commercialized in the form of pills or tablets is recommended by suppliers mainly as a health food, a protein source, vitamin supplement, diet pill and as a treatment for anemia in humans. The commercialization of the alga biomass (processing, packaging and distribution) may introduce environmental pollution or variation of the chemical composition of the product. Cultivation techniques, developed to raise productivity levels so that the increasing demand for these products can be satisfied, may also change the chemical composition [17,3] and consequently the nutritional and toxicological properties of the final products. Furthermore, while chemical composition of algae has been the subject of increasing attention, seldom, have extensive chemical analysis of commercial products been performed.

In this paper, the chemical composition of Spirulina platensis products of both a natural and a commercial Cuban origin and of four commercial (non-Cuban) products available on the Italian market, is reported. The level of macrominerals, trace elements, phycobiliproteins, free and total amino acids, fatty acids has been determined while a method is proposed for the extraction, recovery and determination of phycobiliproteins. The data are also compared with other commercial products based on Spirulina and some parameters are evaluated with reference to Food and Agriculture Organization (FAO) values.

\footnotetext{
* Correspondence and reprints.

$\dagger$ Deceased 28 October 1997.

Correspondence and reprints. Received January 22, 1999; revised April 29,1999; accepted May 10, 1999.
} 


\section{Material and methods}

\section{Algal products}

In table I the origin and commercial characteristics of the products analyzed in this study are reported. The product 1 is natural Spirulina platensis of Cuban origin. The products 2, 3 and 4 are commercial products whereas product 4 contains various Spirulina strains (no details available).

Products 5 and 6 are again commercial products both containing excipients (amounts not specified), while the last one contains material other than Spirulina. Water content was determined by the weight loss of $1 \mathrm{~g}$ of wet material maintained at $105^{\circ} \mathrm{C}$ for $4 \mathrm{~h}$ while ash content was obtained by the weight loss of $1 \mathrm{~g}$ wet material maintained at $500{ }^{\circ} \mathrm{C}$ for $2 \mathrm{~h}$.

\section{Inorganic components}

Macrominerals and trace elements were determined by Instrumental Neutron Activation Analysis (INAA) and by Inductively Coupled Argon Plasma - Atomic Emission Spectroscopy (ICP-AES). The latter has been used to quantify metals not measurable or minimally measurable by INAA $(\mathrm{Cd}, \mathrm{Cu}, \mathrm{Mg}, \mathrm{Mn}, \mathrm{Pb})$. For INAA analysis, the TRIGA MARK II reactor of the ENEA-Casaccia Laboratories (Rome, Italy) has been used. Samples were irradiated, together with standard reference materials, at a neutron flux of $2 \times 10^{12} \mathrm{n} \mathrm{cm}^{-2} \mathrm{~s}^{-1}$ for $28 \mathrm{~h}$. Determination of elements which yield radioisotopes with half-lives of a few minutes or hours has been carried out by irradiation of the samples for $1 \mathrm{~min}$ at a neutron flux 10 fold higher. An agate mortar was used to crush $5 \mathrm{~g}$ of each sample which was then placed in an oven at $80{ }^{\circ} \mathrm{C}$ for $4 \mathrm{~h}$. Five $0.5 \mathrm{~g}$ and five $0.025 \mathrm{~g}$-aliquots were used for the longer and shorter irradiation, respectively. Two standard reference materials were used: the European Inter-Institutes Committee (CII) "Alfa-Alfa" and the Bureau Communautaire de Référence "Lucerna Flour". These reference materials were previously standardized using the NBS-SRM 1573 standard ("Tomato Leaves"). After irradiation, $\gamma$-spectrometry measurements at proper times were carried out using a $\mathrm{Ge}(\mathrm{HP})$ Canberra detector (resolution $1.9 \mathrm{keV}$ ) equipped with a suitable software program.

For ICP-AES analysis, $1 \mathrm{~g}$ of each sample was digested in a Teflon capsule with $10 \mathrm{~mL}$ of $65 \%$ nitric acid and 0.5 $\mathrm{mL}$ of hydrogen peroxide, using a microwave digestion system (CEM, Matthews, NC), for $40 \mathrm{~min}$. Then, the clear solution was filtered on a $0.45-\mu \mathrm{m}$ Millipore (Millipore Co, Bedford, MA) filter.

Filter and container were washed three times with doubly-distilled water which was collected together with the sample solution. The solution was then brought to a final volume of $40 \mathrm{~mL}$ with doubly-distilled water. For the determination of $\mathrm{Ca}, \mathrm{Na}, \mathrm{K}, \mathrm{Fe}$ a further dilution to $100 \mathrm{~mL}$ was needed. Measurements were carried out using a Jobin-Yovin (France) Type III Plus spectrometer. The instrument was calibrated using Spectrosol standards (BDH Chemicals Ltd, Poole, England).

\section{Organic components}

The phycocyanin (C-PC) and Allo-phycocyanin (APC) were extracted and purified from natural and commercial products $(2 \mathrm{~g})$ by slightly modifying a procedure described in the literature [16]. This method is based on the lysis of the bacterial cell walls with lysozyme followed by C-PC, APC and interfering proteins separation by low pressure liquid chromatography (LPLC) on a hydroxylapatite column (Bio-Rad, Richmond, CA) using increasing phosphate concentrations. The compounds have been monitored using "off-line" UVVis (Perkin Elmer, Norwich, CT) detection on 3-mL fractions at $280 \mathrm{~nm}$ (interfering proteins), $620 \mathrm{~nm}(\mathrm{C}-\mathrm{PC})$ and $650 \mathrm{~nm}$ (APC). The appropriate fractions were pooled, concentrated with Aquacide I (Calbiochem, La Jolla, CA) and dialyzed against $100 \mathrm{mM}$ phosphate buffer containing 50 $\mathrm{mM} \mathrm{NaCl}$. Compounds concentration $(\mathrm{mg} / \mathrm{mL})$ has been cal-

Table I. Characteristics and origin of the samples investigated in this study.

\begin{tabular}{|c|c|c|c|c|c|c|c|}
\hline Sample & Organism $\mathrm{C}$ & $\begin{array}{l}\text { Country of } \\
\text { origin }\end{array}$ & $\begin{array}{l}\text { Product, } \\
\text { presentation }\end{array}$ & $\begin{array}{l}\text { Net weight } \\
\quad(g)\end{array}$ & $\begin{array}{l}\text { Recommended } \\
\text { doses }\left(g \text { day }{ }^{-1}\right)\end{array}$ & $\begin{array}{l}\text { Expiration } \\
\text { date (years) }\end{array}$ & Notes \\
\hline 1) Spirulina & Sp. platensis & s Cuba & Dried seaweed, scales & - & - & - & Natural \\
\hline 2) SpirAll & Sp. platensis & $s \quad$ Cuba & Plastic bottles, pills & 20 & $0.8-1.6$ & 3 & Commercial \\
\hline $\begin{array}{l}\text { 3) Spirulina } \\
\text { maxima }\end{array}$ & Sp. maxima & Italy & $\begin{array}{c}\text { Details sale by } \\
\text { weight, dry powder }\end{array}$ & Variable & Not indicated & 2 & Commercial \\
\hline $\begin{array}{l}\text { 4) Spirulina } \\
\text { Messicana }\end{array}$ & Spirulina & Mexico & Plastic bottles, pills & 35 & $1.2-2.4$ & 3 & $\begin{array}{l}\text { Commercial. Mixing of } \\
\text { different } S p \text {. species }\end{array}$ \\
\hline $\begin{array}{l}\text { 5) Spirulina } \\
\text { Health }\end{array}$ & $\begin{array}{l}\text { Sp. sosa and } \\
\text { texcoco }\end{array}$ & USA & Plastic bottles, pills & 30,5 & $1.8-3.7$ & 3 & $\begin{array}{l}\text { Sp. }(60 \% \text { sosa tex. e } 40 \% \\
\text { proteus })+ \text { excipients }\end{array}$ \\
\hline $\begin{array}{l}\text { 6) Alga Marina } \\
\text { Health }\end{array}$ & $\begin{array}{l}\text { Laminaria } \\
\text { and Fucus }\end{array}$ & USA & Plastic bottles, pills & 85 & $1-2$ & e & $\begin{array}{c}\text { Algae }(70 \% \text { Fucus } \\
\text { e 30\% Laminaria })+ \text { excipients }\end{array}$ \\
\hline
\end{tabular}


culated using the specific extinction coefficient of 6.35 for $\mathrm{APC}$ at $650 \mathrm{~nm}, \mathrm{pH} 7.0$ [18] and 7.0 for C-PC at $620 \mathrm{~nm}$, $\mathrm{pH} 7.0$ [19]. Since commercial standards of phycocyanins are not available, this procedure was also used to prepare pure standards of the two compounds. Routine analysis of the extract was performed by HPLC using a Bio-Gel HPHT column, $10 \times 0.78 \mathrm{~cm}, 10 \mu \mathrm{m}$, from Bio-Rad. The elution was performed by using a binary gradient where mobile phase A was phosphate buffer $1 \mathrm{mM}, \mathrm{pH} 7.0$, and mobile phase B was phosphate buffer $250 \mathrm{mM}$, pH 7.0, both containing $0.1 \mathrm{M} \mathrm{NaCl}$ and $1 \mathrm{mM} \mathrm{NaN}_{3}$. The gradient program was the following: 6 min isocratically $(80 \% \mathrm{~A}, 20 \% \mathrm{~B})$ then up to $100 \%$ of B in $2 \mathrm{~min}$, hold for $7 \mathrm{~min}$. It was then necessary to re-equilibrate the column for $10 \mathrm{~min}$ at the initial conditions. The instrument was a Kontron 422 equipped with a UV-Vis detector 430 (Kontron, Everett, MA) and a Rheodyne (Cotati, CA) injection valve mod. 7215 (sample loop $=20 \mu \mathrm{L}$ ). External standards (solutions from the LPLC procedure) were used for quantitative measurements.

Free and total amino acids were extracted from the samples and determined as phenyltiocarbamil (PTC) derivatives by reverse-phase HPLC with UV detection at $254 \mathrm{~nm}$. A Varian 9012 liquid chromatograph (Varian, Palo Alto, CA), equipped with a Varian $9050 \mathrm{UV}$-Vis detector and a Rheodyne 7125 injection loop, was used. The column was a Supelcosil LC 18-DB (Supelco, Bellefonte, PA), $25 \times 0.46$ $\mathrm{cm}$ i.d., $5 \mu \mathrm{m}$, kept at $45^{\circ} \mathrm{C}$ during the analysis.

Extraction of the free amino acids was performed by adding $2.0 \mathrm{~mL}$ of 0.37 trichloroacetic acid (Sigma, St. Louis, MO) to $150 \mathrm{mg}$ of sample previously crushed in an agate mortar and placed in a vial. After homogenization on Vortex for $1.5 \mathrm{~min}$, the sample was added with $0.2 \mathrm{~mL}$ sodium deoxycholate $(0.36 \mathrm{M})$ and left at room temperature for 10 $\mathrm{min}$. After centrifugation (3000 g for $15 \mathrm{~min}$ ) the supernatant was separated, centrifuged again $(5000 \mathrm{~g}$ for $1 \mathrm{~h}$ ) to remove the fine precipitate and separated again.

Extraction of the total amino acids was based on the hot hydrolysis of the proteins and simultaneous solubilization of free amino acids. A 15-mg sample was placed in a vial and with $1 \mathrm{~mL}$ of $6 \mathrm{~N}$ "constant boiling" $\mathrm{HCl}$ (Pierce, Rockford, IL). After nitrogen flushing for $5 \mathrm{~min}$, the vial was screwcapped and placed in an oven at $110^{\circ} \mathrm{C}$ for $22 \mathrm{~h}$. Since tryptophan is destroyed by this procedure [20], a 15-mg sample was separately hydrolyzed with $1 \mathrm{~mL}$ of $4 \mathrm{~N}$ methansulfonic acid (Pierce). After cooling, the hydrolysate was filtered on $0.45-\mu \mathrm{m}$ filters (Whatman, Kent, UK).

The derivatization procedure is similar to that one adopted by Janssen et al. [21]. One hundred microliters or $25 \mu \mathrm{L}$ of the final extracts, obtained for the total and the free amino acids respectively, were added with $25 \mu \mathrm{L}$ of $10^{-}$ ${ }^{3}$ M Norleucine (Nle) used as an internal standard (I.S.) and $25 \mu \mathrm{L}$ of a freshly-prepared solution containing ethyl alcohol-water-triethylamine (TEA)-PITC (7:1:1:1). After $20 \mathrm{~min}$ at room temperature, the samples were dried by rotary evaporation (Büchi, Switzerland) and dissolved in 250 or $500 \mu \mathrm{L}$ of the starting HPLC buffer solution. Cysteine cannot be derivatized under these conditions and transformation in car- boxymethylcysteine (Cm-Cys) with iodioacetic acid is required [22] prior to derivatization. Some authors proposed the addition of iodioacetic acid to the sample before starting the derivatization procedure so that the same aliquot of sample could be used for a simultaneous derivatization of all the amino acids $[23,24]$. We found that this procedure is not reliable when amino acids are present at levels of 2-3 nmoles or lower, probably because of artifacts which are formed during the carboxymethylation and heavily affect the measurement of the other amino acids. Therefore, for the determination of cysteine a separate $200-\mu \mathrm{L}$ aliquot of sample was added with $25 \mu \mathrm{L}$ of I.S. and $25 \mu \mathrm{L}$ of $10^{-1} \mathrm{M}$ iodioacetic acid and left standing for $15 \mathrm{~min}$. After this step, derivatization proceeded as described for the other amino acids.

Analysis of the PTC-amino acids was performed by using a ternary gradient elution at a mobile phase flow-rate of 1.0 $\mathrm{mL} / \mathrm{min}$. The three eluents were: $\mathrm{A}, 0.7 \mathrm{M} \mathrm{CH}_{3} \mathrm{COONa}+$ $2.5 \mathrm{~mL} / \mathrm{L}$ TEA $+\mathrm{CH}_{3} \mathrm{COOH}$ to $\mathrm{pH}$ 6.4; $\mathrm{B}$, water; $\mathrm{C}$, $\mathrm{CH}_{3} \mathrm{CN}-\mathrm{H}_{2} \mathrm{O}$ (80:20). The gradient program was the following: from $20 \% \mathrm{~A}, 75 \% \mathrm{~B}, 5 \% \mathrm{C}$ to $20 \% \mathrm{~A}, 30 \% \mathrm{~B}, 50 \%$ $\mathrm{C}$ in $25 \mathrm{~min}$ then to $10 \% \mathrm{~A}, 10 \% \mathrm{~B}, 80 \% \mathrm{C}$ in $1 \mathrm{~min}$ and hold for $4 \mathrm{~min}$. Ten minutes were then necessary to re-equilibrate the column at the initial conditions. Standard solutions of the single amino acids in $0.1 \mathrm{~N} \mathrm{HCl}$, prepared from the pure compounds (kit D-L Aminoacids from Sigma), were derivatized with the same procedure and identification was carried out either by comparing samples and standard solutions chromatograms or by coelution (addition of selected PTC-amino acids standard solutions to the derivatized samples). For quantitative analysis, the protein hydrolyzate in $0.1 \mathrm{~N} \mathrm{HCl}$ from Pierce ("Amino acid standard H"), added with asparagine, tryptophane and the I.S., derivatized as described above, was used to construct calibration curves.

Fatty acids were extracted using two different procedures. In the first one, $15 \mathrm{mg}$ of sample added with a benzene solution $(10 \mu \mathrm{L})$ of 17:0 (I.S.) were dried and esterified with 2 $\mathrm{mL}$ of $\mathrm{BCl}_{3} / \mathrm{CH}_{3} \mathrm{OH}, 12 \%$ w/w (Perkin Elmer) in sealed vials, at $100{ }^{\circ} \mathrm{C}$ for $30 \mathrm{~min}$. After cooling $1 \mathrm{~mL} \mathrm{H}_{2} \mathrm{O}$ was added and the methyl esters of the fatty acids were extracted with $1 \mathrm{~mL}$ of petroleum ether (Carlo Erba, Milan, Italy). After centrifugation ( $2000 \mathrm{~g}$ for $5 \mathrm{~min}$ ) the organic layer was removed and the extraction repeated 4 times. The extracts were combined, evaporated to dryness and redissolved in $100 \mu \mathrm{L}$ of $n$-hexane. One microliter-aliquots were injected into the gas-chromatograph.

The second procedure was based on supercritical fluid extraction with $\mathrm{CO}_{2}$ using a home-made extractor (Dept. of Engineering, Univ. of Trieste, Italy). Samples of $10 \mathrm{~g}$ were extracted for $1 \mathrm{~h}$ at a pressure and a temperature of $240 \mathrm{~atm}$ and $60{ }^{\circ} \mathrm{C}$, respectively. After cooling and depressurization, the extract was recovered with $\mathrm{CHCl}_{3}$, evaporated to dryness and redissolved in $100 \mu \mathrm{L}$ of $n$-hexane. One microliteraliquots were injected into the gas-chromatograph.

Analyses were performed on a Hewlett-Packard (HewlettPackard, Palo Alto, CA) gas-chromatograph equipped with a SP-2380 fused silica capillary column, $30 \mathrm{~m} \times 0.25 \mathrm{~mm}$ 


\section{Original articles}

i.d. (Supelco) and a flame ionization detector (FID). Injector and detector temperature was $250{ }^{\circ} \mathrm{C}$ while the column temperature program was $3{ }^{\circ} \mathrm{C} / \mathrm{min}$ from $30{ }^{\circ} \mathrm{C}$ up to $220{ }^{\circ} \mathrm{C}$. Identification and quantification were carried out using mixtures of authentic fatty acids methyl esters containing the I.S.

\section{Results and discussion}

The water and ash content of all the samples reported in table I is $8-13 \%$ and $9-15 \%$, respectively. These values are similar to those ones reported for natural and commercial Spirulina and for other algae [25-28].

\section{Inorganic components}

Table II shows the macromineral and the trace elements content of the same samples. With respect to the values reported for other natural products [26,28] the Ca level in Sample 1 is 3 to 10 times higher, the $\mathrm{K}$ level is similar and the $\mathrm{Mg}$ level is about one third the reference level. The Na concentration for a natural product is within the variability range which depends on the salinity of the harvesting site (natural ponds) or on the addition of $\mathrm{Na}$ salts added in the formulation of the culture medium (artificial ponds). In general, also the macromineral content of the commercial Spirulina based products is within the variability range of similar products reported in the literature [25,28]. Similar concentrations of $\mathrm{K}, \mathrm{Cl}$ and $\mathrm{Mg}$ are found in our commercial Spirulina products (Samples 2 through 5) while $\mathrm{Ca}$ and $\mathrm{Na}$ show some variability. In particular, the $\mathrm{Na}$ level in the commercial product (Sample 2) obtained from the natural product (Sample 1) decreases by about $50 \%$, indicating the loss of this element during the industrial processing. The $\mathrm{Na} / \mathrm{K}$ ratio, which is important from the nutritional point of view because high ratio of $\mathrm{Na} / \mathrm{K}$ can cause hypertension, is below 2.6 for both our natural and commercial Spirulina products and similar in some cases, to the $\mathrm{Na} / \mathrm{K}$ ratios found in analogous commercial products, of different country of origin, available in Spain [25] and in the USA [28]. High levels of

Table II. Macromineral and trace elements contents of the products studied. *Elements determined by ICP-AES. All the others by INAA. Values are the mean (RSD in brackets) of five determinations. N.D.: not detected.

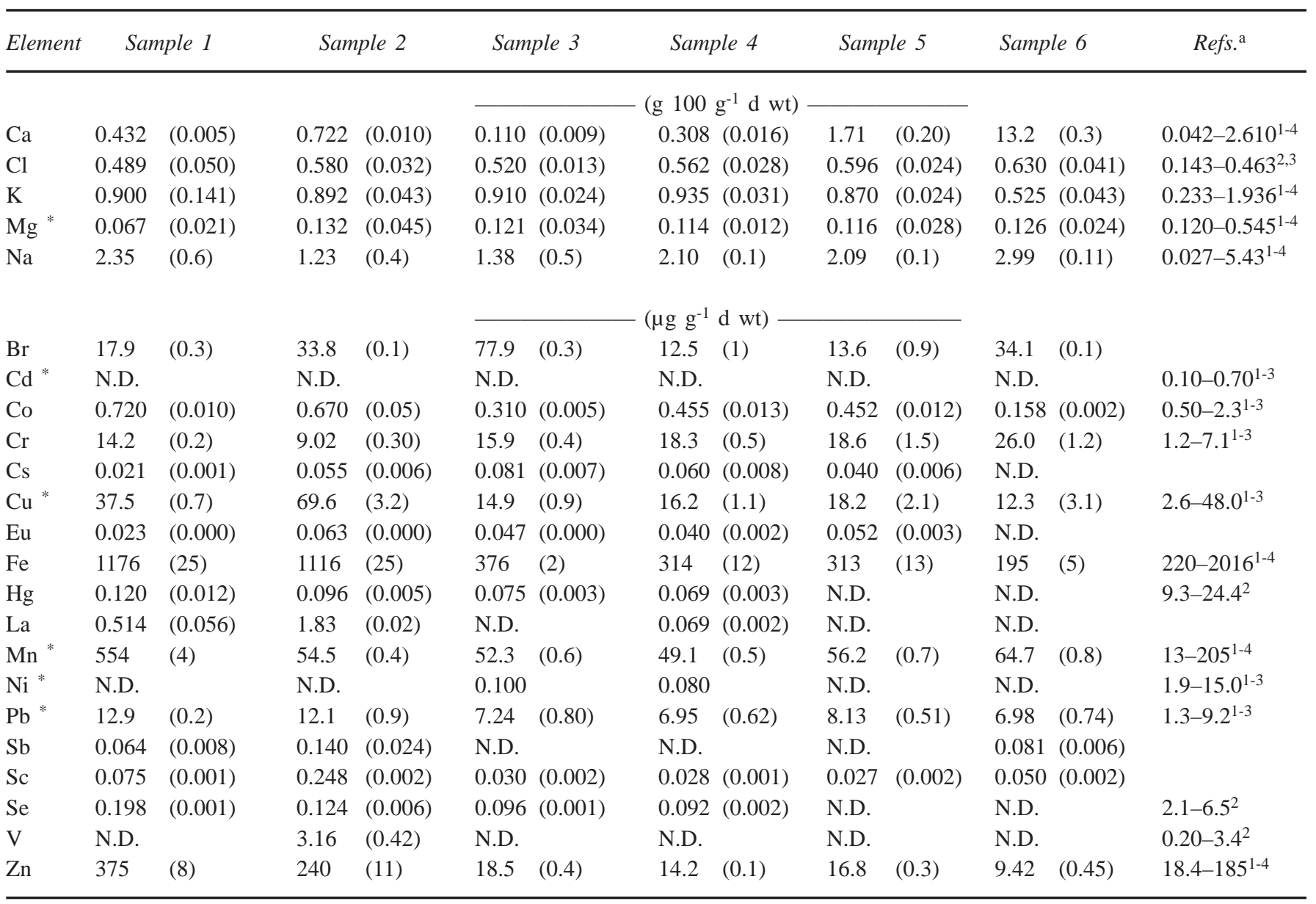

aReferences: 1. (Ortega-Calvo et al., 1993); 2. (Dillon et al., 1995); 3. (Mannino and Benelli, 1980); 4. (Johnson and Shubert, 1986). 


\section{Original articles}

$\mathrm{Ca}$ and a higher $\mathrm{Na} / \mathrm{K}$ ratio are found in Sample 6, a non Spirulina algal product, probably because of a high amount of excipients added to the formulation of the product.

With regard to trace elements, all the products show concentration values for iron within the wide range observed in other studies. It should be pointed out that the iron content is high in both the natural and commercial products of Cuban origin. This is important since it has been demonstrated in experiments with rats fed fresh Spirulina that iron is well absorbed and the content is much higher than in other plants. However, the Fe availability can be limited by the presence of $\mathrm{Ca}$ and $\mathrm{P}$, and the composition of other foods present in the diet. $\mathrm{Cd}, \mathrm{Ni}$, and $\mathrm{V}$ have not generally been found in our products; if present their concentrations resulted near the detection limits with the exception of $\mathrm{V}$ in Sample 2. $\mathrm{Hg}$, as well as $\mathrm{Se}$, is much below literature data showing that these products are much safer. On the opposite, $\mathrm{Cr}$ is present in all samples with levels well above the range found in other studies. $\mathrm{Cr}$ is a toxic metal whose metabolism is distinct from that of other trace elements because of its strict dependence on the chemical form $(\mathrm{Cr}$ III/Cr VI). In fact, Cr (III) has a low order of toxicity and a wide margin of safety exists between the amount usually ingested and the amounts needed to induce adverse effects, whereas $\mathrm{Cr}(\mathrm{VI})$ is much more toxic and oral administration of excessive levels has been associated with stunted growth and liver and kidney damage [29].

A peculiar situation arises with $\mathrm{Cu}, \mathrm{V}, \mathrm{Pb}, \mathrm{Mn}$ and $\mathrm{Zn}$. While the levels of these trace elements in most of the commercial products fit with previous data on analogous products, Samples 1 and 2 show anomalous values which are also a proof of the changes introduced in the chemical composition of the biomass by the industrial processing. $\mathrm{Cu}$ and $\mathrm{V}$ are present at higher concentrations in the commercial product with respect to the natural one of the same origin, showing that these elements have been introduced during the commercialization step, while $\mathrm{Mn}$ and $\mathrm{Zn}$ concentrations have been strongly lowered by some removal process. On the contrary the $\mathrm{Pb}$ level does not change significantly and is higher with respect to all other samples and literature data. This is probably caused by local contamination of the production sites and limits the intake of the Cuban commercial product (Sample 2). However, since the maximum allowed daily intake of $\mathrm{Pb}$ is $500 \mu \mathrm{g}$, about $42 \mathrm{~g}$ of this product could be consumed daily by an individual; this is well above the recommended dose (0.8-1.6 g/day). La, Eu (as well as $\mathrm{Cs}$ and $\mathrm{Sc}$ ) have been measured with the purpose of establishing the homogeneity of the sample analyzed [30] since these elements can not be adsorbed by the algae (and by any material) from the environment. The coefficient of variation for five analysis of the same sample (RSD) varies from $1 \%$ to $5 \%$ for the commercial product and is about $10 \%$ for the natural one.

\section{Organic components}

A novel method for the extraction and determination of the phycocyanins, C-PC and APC, in algal samples, based on a
Table III. C-Phycocyanin (C-PC) and Allophycocyanin (APC) content in the various samples. N.D.: not detected.

\begin{tabular}{lccc}
\hline & $C-P C(g / 10 g)$ & $A P C(g / 10 g)$ & Total $(\%)$ \\
\hline Sample 1 & $0.969 \pm 0.003$ & $0.560 \pm 0.056$ & 15.3 \\
Sample 2 & $0.760 \pm 0.021$ & $0.747 \pm 0.012$ & 15.1 \\
Sample 3 & $0.715 \pm 0.013$ & $0.706 \pm 0.039$ & 14.2 \\
Sample 4 & $0.639 \pm 0.045$ & $0.628 \pm 0.049$ & 12.7 \\
Sample 5 & $0.276 \pm 0.022$ & $0.294 \pm 0.032$ & 5.7 \\
Sample 6 & N.D. & N.D. & - \\
\hline
\end{tabular}

modified LPLC [16] and on HPLC methods, has been set up. For both compounds, higher recoveries than reported in the literature [16] have been obtained. From $10 \mathrm{~g}$ of the natural Spirulina product of Cuban origin, approximately 750 $\mathrm{mg}$ of C-PC and $380 \mathrm{mg}$ of APC have been isolated using LPLC, and $970 \mathrm{mg}$ and $560 \mathrm{mg}$ using HPLC. These values are at least 10-fold higher than reported by Jung and Dailey [16] (80 mg and $40 \mathrm{mg}$ ) from $10 \mathrm{~g}$ of Spirulina for C-PC and APC, respectively. The LPLC method requires quite long times for purification $(\sim 5 \mathrm{~h})$ but obviously large volumes of samples $(\sim 5 \mathrm{~mL})$ can be processed using a simple apparatus. On the contrary, the HPLC method requires a more sophisticated instrumentation and smaller volumes of samples $(20-100 \mu \mathrm{L})$ can be purified and analyzed in a single run. However, only $25 \mathrm{~min}$ are required in this case. Taking into account all these factors the approximate costs have been estimated in $0.03 \$ / \mathrm{mg}$ for the method based on LPLC and $0.06 \$ / \mathrm{mg}$ for the method based on HPLC. Therefore, Spirulina can be considered a convenient and inexpensive source of these important products studied in this work. Sample 5 contains a lower amount of phycobiliproteins and, again, this is consistent with the fact that this product, a mixture of Spirulina sosa-texcoco, contains a high percentage of excipients. Phycocyanins are absent in Sample 6, as expected, since this product is obtained from Laminaria and Fucus and Spirulina is the only algal genus which may contain these proteins [31].

The amino acids (protein + free) profiles together with the total amount of amino acids present in each algal product, are reported in table IV. We determined separately also the free amino acids profiles but the relative data are not reported since the contribution to the total amino acids content is only 2\%. The $N$-protein content is higher in Sample $1(694 \mathrm{mg} / \mathrm{g}, \sim 70 \%$ of the dry biomass) while Samples 2 and 3 show quite similar values. This value is still good in Samples 4 and 5, though 20-30\% lower than in the first two samples, while it is very low in Sample $6(3.8 \mathrm{mg} / \mathrm{g}$ dry biomass). Such inter-sample differences are observed also for the content of the single amino acids with the exception of histidine, which is present at the same concentration level $(\sim 6-7 \mathrm{mg} / \mathrm{g})$ in Samples 1 through 5 .

Since literature data [1] report that the total amino acid content of Spirulina should be $60-70 \%$ of the dry biomass, 


\section{Original articles}

Table IV. Amino acids profiles and total amino acids content $\left(\mathrm{mg} \mathrm{g}^{-1} \mathrm{~d} \mathrm{wt}\right)$ of the algal products. Values are the mean (relative standard deviation in brackets) of five determinations. N.D.: not detected.

\begin{tabular}{|c|c|c|c|c|c|c|}
\hline Amino acid & Sample 1 & Sample 2 & Sample 3 & Sample 4 & Sample 5 & Sample 6 \\
\hline \multicolumn{7}{|l|}{ Essential } \\
\hline Ile & $42(2)$ & $41(1)$ & $39(3)$ & $19(1)$ & $31(3)$ & $0.285(0.016)$ \\
\hline Leu & $61(3)$ & $56(5)$ & $53(4)$ & $34(3)$ & $51(1)$ & $0.181(0.017)$ \\
\hline Lys & $34(2)$ & $35(3)$ & $36(2)$ & $27(2)$ & $39(1)$ & $1.44(0.05)$ \\
\hline Met & $17(1)$ & $16(1)$ & $17(2)$ & $7(1)$ & $9(1)$ & $0.241(0.061)$ \\
\hline Phe & $31(1)$ & $29(2)$ & $27(2)$ & $24(1)$ & $29(1)$ & N.D. \\
\hline Thr & $33(2)$ & $30(3)$ & $29(2)$ & $21(1)$ & $24(1)$ & $0.099(0.007)$ \\
\hline Trp & $11(1)$ & $10(1)$ & $10(1)$ & $5(1)$ & $7(1)$ & $0.122(0.010)$ \\
\hline Val & $60(2)$ & $54(3)$ & $52(2)$ & $41(3)$ & $43(5)$ & $0.152(0.016)$ \\
\hline \multicolumn{7}{|l|}{ Non-essential } \\
\hline Ala & $58(1)$ & $51(1)$ & $47(1)$ & $35(2)$ & $43(4)$ & $0.189(0.016)$ \\
\hline Arg & $51(1)$ & $4(8)$ & $48(7)$ & $41(1)$ & $38(4)$ & $0.121(0.008)$ \\
\hline Asp & $60(3)$ & $64(5)$ & $64(3)$ & $48(5)$ & $54(5)$ & $0.178(0.011)$ \\
\hline $\mathrm{Cys}+(\mathrm{Cys})_{2}$ & $5(0)$ & $5(0)$ & $4(0)$ & $2(0)$ & $3(0)$ & N.D. \\
\hline Glu & 101(3) & $89(7)$ & $96(5)$ & $90(6)$ & $86(5)$ & $0.282(0.022)$ \\
\hline Gly & $43(1)$ & $39(1)$ & $39(1)$ & $32(2)$ & $28(4)$ & N.D. \\
\hline His & $6(1)$ & $6(1)$ & $7(1)$ & $7(2)$ & $6(1)$ & N.D. \\
\hline Pro & $27(3)$ & $22(2)$ & $21(3)$ & $19(1)$ & $20(1)$ & $0.115(0.018)$ \\
\hline Ser & $25(3)$ & $23(2)$ & $23(3)$ & $19(2)$ & $25(3)$ & $0.224(0.001)$ \\
\hline Tyr & $29(1)$ & $30(1)$ & $29(2)$ & $18(1)$ & $12(1)$ & $0.091(0.012)$ \\
\hline Total & 694 & 648 & 641 & 491 & 548 & 3.87 \\
\hline
\end{tabular}

the value in Samples 4, 5 and 6 have to be considered anomalous. In the case of Sample 5, this can be easily explained with the presence of excipients, while for Sample 4 the content of $491 \mathrm{mg} / \mathrm{g}$ is not consistent with the information available from the product label. However, a tentative explanation can be found by considering and comparing the concentration values of fatty acids (see later). With regard to Sample 6 the only explanation, confirmed by fatty acids pattern, is that this product is mainly composed by excipients, whereas the algae are present in very small amounts.

Table $\mathrm{V}$ shows the content range of four amino acids (expressed as $\mathrm{mg} / \mathrm{g}$ protein) for Samples 1-5 and for other food products. The four amino acids are: lysine, sulfur amino acids (cysteine+methionine), threonine and tryptophane. We choose these amino acids to compare our products' content to the FAO protein's content [32]. The level of amino acids in the five samples are of the same order of magnitude of the FAO amino acid pattern with the only exception of lysine. Because of the high level of lysine, Spirulina could be considered a protein integrator of cereals (WHO, 1985). For the sulfur amino acids a range lower than the FAO value in two products (Sample 4 and 5) is observed, for that reason we can consider the sulfur amino acids as a limiting amino acids in these products.
The fatty acids composition of each product, expressed as weight percentage of total fatty acids, together with the polyunsaturated/saturated fatty acids ratio (PUN/SAT) are reported in table VI. Generally, all products show a similar composition, the major fatty acids being 16:0, 16:1, 18:0, 18:1, 18:2 and 18:3 $\gamma(\gamma$-linolenic acid, GLA) as reported in the literature for Spirulina strains [11,33] and commercial Spirulina products [25]. A high percentage of 16:0 (palmitic) acid is present in all samples. Very low percentage of 18:0 (stearic) acid is found in the first three samples, while Samples 4-6 show quite high levels (20-40\%). This value is anomalous, being typical of lard and bacon fat and the lower $N$-protein content of Sample 4 can be due to the presence of high amounts of stearic acid which was introduced during the processing of the natural product either by addition or by improper functioning of some treatment phase. In that case it could be interesting to analyze the biomass before the industrial treatment performed to obtain pills.

The GLA, a very important essential fatty acid, is present at levels lower than previously reported by Cohen et al. [23] for Spirulina strains and within the range of some commercial products [25]. An exception is again Sample 6 which does not contain Spirulina. The lower content of this acid in Sample 1 and 2 could be explained by the fact that the Spirulina of Cuban origin is grown under different condi- 


\section{Original articles}

Table V. Comparison of the amino acids pattern $(\mathrm{mg} / \mathrm{g}$ protein) in the FAO "ideal" protein, in some common foods and in the algal products studied.

\begin{tabular}{lcccc}
\hline & Lysine & Cys + Met & Threonine & Tryptophane \\
\hline Pattern FAO & 16 & 17 & 9 & 5 \\
Sample 1-5 & $26-39$ & $8-21$ & $21-33$ & $5-12$ \\
Egg & 61 & 31 & 51 & 16 \\
Casein & 69 & 21 & 43 & 14 \\
Soy flour & 58 & 20 & 40 & 16 \\
\hline
\end{tabular}

tions which may change the content of GLA. However, Samples 1-5 are, or are made from, authentic Spirulina strains since they display a significant proportion of GLA, no $\alpha$-linolenic acid (ALA) and a low content $(\leq 10 \%)$ of 16:1 [34].

The nutritional value of foods increases with the polyunsaturated fatty acids content 0.45 being the minimum PUN/SAT ratio value for a recommended human diet [35]. Three of the products examined are well above this threshold value while Sample 4 and 5 are below the threshold. However, it has been pointed out that exposure of the algal biomass to sunlight for several days may affect PUN fatty acids content [35] because of the photoxidation processes [36]. Under this aspect, possible changes during marketing should be also considered.

\section{Conclusions}

The results show that the food products based on Spirulina can be considered a valid alimentary source for the chemical and nutritional composition. On the basis of our results, we believe that Spirulina platensis of Cuban origin presents the best nutritional values even if the high value of $\mathrm{Pb}$ limits the recommended dose for consumers.

\section{Acknowledgments}

The authors are indebted to I. Kikic and A. Cortesi of the Univ. of Trieste and to M. Vincenzini and A. Bastianini of the University of Florence, for the precious help in the extraction and GC analysis of fatty acids. The authors wish also to thank M. Cresta of the Univ. of Rome for the helpful discussion on the nutritional aspects and L. Angiello for assisting in the LPLC and HPLC determinations.

This work has been partially supported by the Italian National Research Council (CNRCT 93.01557.11). The research was financially supported by CNR, Italian National Research Council, "Progetto Finalizzato Tecnologie Chimiche Innovative".

\section{References}

1. Henrikson, R. Earth Food Spirulina. How this remarkable blue-green algae can transform your health and our planet, Ronore Enterprises Inc., Laguna Beach, California; 1989, pp 180.

2. Ciferri, O. Microbiol. Rev. 1983, 47, 551-578.

Table VI. Fatty acids profile (weight $\%$ of total fatty acids) and total content (\% of dry biomass) and PUN/SAT ratio of the algal products. N.D.: not detected. TR: trace. (t: trans; c: cis).

\begin{tabular}{|c|c|c|c|c|c|c|}
\hline Fatty acid & Sample 1 & Sample 2 & Sample 3 & Sample 4 & Sample 5 & Sample 6 \\
\hline $14: 0$ & N.D. & N.D. & N.D. & TR & N.D. & N.D. \\
\hline $16: 0$ & 65.1 & 64.3 & 59.7 & 53.2 & 59.3 & 56.2 \\
\hline $16: 1 \mathrm{t}$ & N.D. & N.D. & N.D. & TR & TR & TR \\
\hline $16: 1 \mathrm{c}$ & 12.4 & 8.2 & 10.2 & 5.2 & N.D. & N.D. \\
\hline $17: 1$ & 1.7 & 1.5 & 1.6 & TR & N.D. & N.D. \\
\hline 18:0 & 1.3 & 1.1 & 1.1 & 21.3 & 18.3 & 42.3 \\
\hline $18: 1$ & 4.1 & 4.5 & 2.7 & $\mathrm{TR}$ & 2.3 & 0.8 \\
\hline $18: 2$ & 12.3 & 14.2 & 13.3 & 9.1 & 11.1 & 0.5 \\
\hline $18: 3 \gamma$ & 3.1 & 5.1 & 13.4 & 11.2 & 8.8 & 0.2 \\
\hline $18: 3 \alpha$ & TR & N.D. & N.D. & N.D. & N.D. & N.D. \\
\hline $18: 4$ & N.D. & TR & N.D. & N.D. & N.D. & N.D. \\
\hline $20: 2$ & TR & N.D. & TR & N.D. & N.D. & N.D. \\
\hline 24:0 & N.D. & N.D. & N.D. & N.D. & N.D. & N.D. \\
\hline $24: 1$ & N.D. & 1.1 & N.D. & TR & 0.2 & $\mathrm{TR}$ \\
\hline Totals & 2.4 & 4.6 & 2.7 & 2.8 & 2.1 & 2.2 \\
\hline Pun/Sat & 0.51 & 0.53 & 0.64 & 0.34 & 0.29 & 0.02 \\
\hline
\end{tabular}




\section{Original articles}

3. Richmond, A. Spirulina. In Micro-Algal Biotechnology, Borowitzka, M. A. and Borowitzka, L. J. Eds., Cambridge University Press, 1988.

4. Narasimha, D. L. R.; Venketaraman, G. S.; Duggal, S. K.; Eggun, B. O. J. Sci. Food Agric. 1982, 33, 456.

5. Richmond, A. Microalgae of economic potential. In: $C R C$ Handbook of Microalgal Mass Culture; Richmond, A. Ed., CRC Press: Boca Raton, FL, 1986, pp 199-244.

6. Switzer, L. Spirulina, the whole food revolution; Bantam Books: New York, 1982.

7. Jassby, A. Nutritional and Therapeutic Properties of Spirulina; Draft for Proteus Corporation, 1983, p 135.

8. Jassby, A. Spirulina: a model for microalgae as human food. In: Algae and Human Affairs; Lembi, C. A.; Waaland, J. R. Eds., Cambridge University Press, Cambridge, 1988; pp 149179.

9. Schwartz, J.; Scklar, G.; Suda, D. Cancer Nutrition 1988, June.

10. Roughan, P. G. J. Sci. Food Agric. 1989, 47, 85.

11. Cohen, Z.; Vonshak, A.; Richmond, A. Phytochem. 1987, 26, 2255-2258.

12. FAO. Blue-green algae for rice production. FAO Soils Bulletin, FAO: Rome, Italy, 1981.

13. Metting, B. Micro-algae in agriculture. In Micro-Algal Biotechnology, Bororwitzka Ed., Cambridge University Press, Cambridge, 1988.

14. Kosaric, N.; Nguyen, H. T.; Bergougnon, M. A. Biotechnol. Bioeng. 1974, 16, 881.

15. Sakaria, R.; MacGillivray, A.J. Biochem. Soc. Trans. 1989, 17, 605.

16. Jung, T. M.; Dailey, M. O. J. Immunol. Meth. 1989, 121, 915.

17. Chapman, V. J.; Chapman, D. J. Seaweed and their uses. Chapman and Hall, London, UK, 1980, pp 334.

18. Brown, A. S.; Troxler, R. F. Biochem. J. 1977, 163, 571.

19. Hardy, R.R. Purification and coupling of fluorescent proteins for use in flow citometry. In: Handbook of Experimental Immunology; Weir, D.; Herzenberg, L. A.; Blackwell, H.;
Herzenberg, L. A. Eds, Blackwell Sci. Publications, Oxford, U.K., 1986, p 31.

20. Chiou, S. H.; Wang, K. T. J. Chromatogr. 1988, 448, 404-410.

21. Janssen, P. S. L.; van Nispen, J. W.; Melgers, P. A. T. A.; van den Bogaart, H. W. M.; Hamelinck, R. L. A. E.; Goverde, B. C. Chromatographia 1986, 22, 345-350.

22. Cooper, J. D. H.; Turnell, D. C. J. Chromatogr. 1982, 227, 158-161.

23. Cohen, S. A.; Bidlingmeyer, B. A.; Tarvin, T. L. Nature 1986, 320, 769-770

24. Cohen, S. A.; Strydom, D. J. Anal. Biochem. 1988, 174, 1-16.

25. Ortega-Calvo, J. J.; Mazuelos, C.; Hermosin, B.; Saiz-Jimenez, C. J. Appl. Phycol. 1993, 5, 425-435.

26. Dillon, J. C.; Phuc, A. P.; Dubacq, J. P. World Rev. Nutr. Diet. 1995, 77, 32-46.

27. Mannino, S.; Benelli, T. G. Costituenti minerali di biomasse di Spirulina maxima. In: Prospettive della cultura di Spirulina in Italia; Materassi, R. Ed., CNR, Rome, 1980; pp 131-135.

28. Johnson, P. E.; Shubert, L. E. Nutr. Rep. Int. 1986, 34, $1063-$ 1070.

29. Prasad, A. S. Chromium. In: Trace Elements and Iron in Human Metabolism, Prasad, A.S., Ed., Plenum Medical Book Company, New York and London, 1978; pp 1-15.

30. Guzzi, G.; Colombo, A.; Girardi, F.; Pietra, R.; Rossi, G.; Toussaint, N. J. Radioanal. Chem. 1977, 39, 263-277.

31. Margheri, M. C.; Tomaselli Feroci, L.; Materassi, R. Contributo sperimentale alla sistematica del genere Spirulina turpin, In: Proceedings of the XVII National Congress of Ital. Microbiol. Soc., Padova, Italia, 1975; p 891.

32. WHO. Energy and protein requirements. Draft report. Italian Edition. Milan, Italy, 1985.

33. Cohen, Z.; Vonshak, A. Phytochem. 1991, 30, 205-206.

34. Cuthbertson, W. F. J. Food Chem. 1989, 33, 53-80.35.

Soong, P. Production and development of Chlorella and Spirulina in Taiwan. In: Algae Biomass; Shelef, G.; Soeder, C. J. Eds., Elsevier, Amsterdam, 1980, pp 97-113.

36. Lundberg, L. G. J. Am. Oil Chem. Soc. 1954, 31, 523-528. 